УДК 351.71:174:61

П. В. Герасименко, к. мед. н.,

О. В. Герасименко, к. іст. н., доцент

\title{
ЕТИЧНІ АСПЕКТИ РОЗБОРУ СКАРГ У ПРИВАТНІЙ МЕДИЧНІЙ ПРАКТИЦІ
}

Актуальність теми дослідження. Актуальність дотримання принципів медичної етики під час розбору скаре визначається складністю прийняття рішень під час експертизи невідповідностей медичної практики, обов'язковим елементом якої є втручання в особистий внутрішній світ людини.

Постановка проблеми. Структура скаре щодо діяльності медичних працівників $є$ досить складною. Не завжди рішення після розбору скарги є на користь скаржника. В той же час невідповідності медичної практики з вини медичного закладу мають суттєві наслідки: організаційні, фрінансові, іміджеві. Тому вдосконалення та належне застосування принципів медичної етики під час розбору скарг є важливим на всіх етапах медичної допомоги.

Аналіз останніх досліджень і публікацій. В статті згадуються роботи науковців та практиків медичної діяльності, які узагальнюють масив знань з проблематики дотримання медичної етики під час медичного втручання та ймовірних скарг.

Виділення недосліджених частин загальної проблеми. На сучасному етапі розвитку національна система охорони здоров'я перебуває в стані кардинальних змін. Суттєво перерозподіляються частки державного, комунального та приватного секторів. Динамічно змінюються їх структура та тренди розвитку. Мінливість теперішньої національної системи охорони здоров'я потребує більш досконалого вивчення і висвітлення, за для корисного обміну досвідом та впровадженням найкращих практик етичного поводження з пацієнтом.

Постановка завдання. Метою публікації є розширення науково-практичних знань та навичок про гармонійну інтеграцію принципів медичної етики в сучасну українську медицину.

Виклад основного матеріалу. Розглянуті варіанти скарг від незадоволених пацієнтів, етичні принципи підходу до їх розгляду, етапи та особливості розбору скарг, ролі кожного з медичних працівників під час таких розборів.

Висновки. У публікації розглянуто практичний досвід застосування принципів медичної етики та деонтології в роботі приватного медичного закладу при розборі скарг. Обговорено основні елементи етичного підходу при проведенні діагностики, розгляду та вирішенні скарги. Описано умови та процеси, що супроводжують комунікацію зі скаржниками. Запропоновано варіанти підходів до розв'язання завдань до персоналу клінік та фріналізації усунення виявлених невідповідностей.

Ключові слова: медична етика; клієнт; скарга; приватна медична практика.

P. V. Herasymenko, Candidate of Medical Sciences, O. V. Herasymenko, Candidate of Historical Sciences, Associate Professor

\section{ETHICAL ASPECTS OF HANDLING COMPLAINTS IN PRIVATE MEDICAL PRACTICE}

Urgency of the research. The relevance of adherence to the principles of medical ethics in the analysis of complaints is determined by the complexity of decision-making during an examination of inconsistencies in medical practice, which mandatory element is interference in a person's inner world.

Target setting. The structure of complaints about activities of health professionals is quite complex. A decision after a complaint is not always in favor of a complainant. At the same time, inconsistencies in medical practice due to a fault of a medical institution have significant consequences: organizational, financial, image. Therefore, improvement and proper application of principles of medical ethics in complain handling is important at all stages of medical care.

Actual scientific researches and issues analysis. The article mentions works of scientists and medical practitioners, summarizes the body of knowledge on the issues of adherence to medical ethics during medical intervention and possible complaints. 
Uninvestigated parts of general matters defining. At the present stage of development, the national health care system is in a state of radical change. The shares of the public, communal and private sectors are significantly redistributed. Their structure and development trends are changing dynamically. The volatility of the current national health care system requires better study and coverage, in order to share experiences and implement best practices in ethical patient management.

The research objective of the publication is to expand scientific and practical knowledge and skills about the harmonious integration of the principles of medical ethics in modern Ukrainian medicine.

The statement of basic materials. Variants of complaints from dissatisfied patients, ethical principles of the approach to their consideration, stages and features of complaint analysis, the role of each of the medical staff during such examinations are considered.

Conclusions. The publication discusses the practical experience of applying the principles of medical ethics and deontology in the work of a private medical institution in the analysis of complaints. The main elements of an ethical approach to diagnostics, consideration and resolution of a complaint. The conditions and processes that accompany communication with the complainant are described. Variants of approaches to solving problems for the personnel of clinics and finalizing the elimination of the identified inconsistencies are proposed.

Keywords: medical ethics; client; complaint; private medical practice.

DOI: 10.25140/2412-1185-2019-2(14)-13-18

Актуальність теми дослідження. На сучасному етапі розвитку національної системи охорони здоров'я приватні медичні заклади невпинно демонструють наполегливе зростання частки населення та території власного обслуговування. У відповідності до зазначеної тенденції зростає і конкуренція як між державним та приватним сектором медицини, так і поміж приватними клініками. Загальновизнаними та одними із найефективніших способів конкурування в сфері охорони здоров'я є постійне підвищення якості медичних послуг та фоормування гнучкої політики лояльності до клієнтів. Однак, незважаючи на це, повсякденна практика вказує на збереження значної кількості клієнтів, які залишаються невдоволеними після відвідування приватних медичних закладів, що і стає підґрунтям для формування різноманітних скарг. Приватна медична практика найбільш чутлива до таких обставин. Докладний розбір скарг та відповідна комунікація з клієнтом, з дотриманням норм медичної етики, дозволяє оперативно усувати та\або попереджувати недоліки в роботі. Це підвищує якість надання медичних послуг та сприяє досягненню задоволення потреб клієнтів. Тому, застосування принципів етики та деонтології в медицині з невдоволеними клієнтами є обов'язковим елементом роботи персоналу приватних клінік.

Виклад основного матеріалу. Клініка ТЕСЛА $€$ одним з провідних приватних медичних закладів Чернігівщини і забезпечує високу пріоритетність дотримання принципів етики та деонтології й особливо при комунікації із скаржниками, навіть, із безпідставними скаргами й так званими «професійними скаржниками», які наполегливо «перевіряють» лікарів.

Менеджмент клініки провадить постійний процес управління якістю всіх без винятку бізнеспроцесів. Зважаючи на розмаїття скарг та каналів їх надходження, для систематизації та ретельного розбору розроблений відповідний стандарт, етапний алгоритм та електронний журнал. Зазначений підхід до отриманої скарги дозволяє забезпечити дотримання основних етичних принципів поводження зі скаржниками, а саме:

1. Швидкість реагування на невдоволення клієнта;

2. Правильна діагностика скарги;

3. Демонстрація персональної уваги до скаржника;

4. Залучення перших осіб клініки;

5. Обов'язкове виконання обіцяних результатів;

6. Задоволення потреби клієнта щодо проблеми зі здоров'ям.

Серед відвідувачів амбулаторно-поліклінічних закладів реєструються переважно пацієнти 3 первинними зверненнями або "хронічні клієнти» з тривалими захворюваннями. В першому випадку, нова проблема зі здоров'ям викликає у людини тривогу та страхи за своє майбутнє, створює проблеми з працездатністю та самообслуговуванням. В другому випадку, пацієнти часто бувають вже втомлені від хвороби та стають недовірливими і дуже вразливими. Тому, 
швидкість реагування фронт-офісу на скаргу є дуже важливим. Клієнт безумовно очікує на оперативне вирішення своїх проблем із здоров'ям. Персонал клініки постійно навчається та підвищує свій професіоналізм для раннього виявлення невдоволення клієнтів. Своєчасна діагностика проблеми дозволяє клієнту та клініці запобігти зайвим витратам часу, непотрібним психо-емоційним навантаженням та уникнути формульованої та документованої скарги. Невиявлена прихована невдоволеність відвідувача залишає його з проблемним здоров'ям та погіршує якість життя. Тому, персонал повинен вміти визначати таку невдоволеність, швидко вирішувати проблему або коректно та компетентно запропонувати клієнту чітко сформулювати скаргу. При комунікації зі скаржником фронт-офіс повинен гармонійно об'єднувати швидкість своєї роботи з її якістю. Не можна допускати поспіху, метушні або розгубленості. Адміністратор повинен демонструвати впевненість, лаконічність, ефективність, що сприяє результативності для відвідувача та його впевненості, що проблема буде вирішена в найкоротшій час. Пролонгація діагностики скарг, а відповідно й відтермінування медичної допомоги прямо суперечить головній заповіді медичної етики: Primum non nocere! Фраза «Найперше - не зашкодь!» ще 3 середини XIX сторіччя стала для лікарів «священним» виразом належного ставлення до хворого, професійної смиренності та визнання того, що часом дії людини навіть 3 добрими намірами, можуть мати небажані наслідки.

Правильність діагностування невдоволення клієнта в приватній медицині має принципове значення для обрання відповідного методу реагування. Усі вище зазначені невідповідності роботи можна класифікувати наступним чином:

1. Приховане невдоволення;

2. Формульована скарга;

3. Усна суперечка;

4. Скандал.

При розгляді цих варіантів поведінки скаржників слід актуалізувати дві наступні тези. Перша теза. Етична комунікація з клієнтом повинна забезпечити конвертацію першого, третього та четвертого варіантів у другій. Це дозволить пацієнту якомога скоріше отримати бажаний результат. Є рекомендації щодо залучення самих клієнтів до такої конвертації. Цей аспект відповідає сучасній тенденції медичної етики, яка все більше набуває собі прихильників в Україні, а саме, партнерська модель спілкування з пацієнтом. Такий підхід в умовах сучасного інформаційного суспільства є більш ефективним, тому що, чітко формульована скарга стає своєрідним «подарунком» для клініки. Корисна, об'єктивна інформація про будь-які невідповідності дозволяє індивідуалізувати та покращувати послугу. Клієнт стає більш залученим до процесу, що сприяє етичним вимогам про довіру та гуманізацію медицини. В менеджменті скарг та невдоволень «вищим пілотажем» вважається вирішення проблеми клієнта з поступовим перетворенням його із скаржника на партнера та промоутера клініки. Друга теза. Згадані перший, третій та четвертий варіанти при несвоєчасному вирішенні можуть набувати деперсоналізованого, публічного, демонстративного перебігу. Приватна клініка, в тому числі з етичних та іміджевих міркувань не може допускати вимушеного або добровільного залучення інших клієнтів та персоналу до спостерігання розбору скарги або скандалу. Навіть в разі стикання з людьми схильними до суперечок або «професійними» скаржниками персонал має швидко локалізувати проблему окремо від інших відвідувачів і персоналу та діяти за відповідним алгоритмом. Індивідуалізація розбору скарги є єдиним етичним варіантом, він дає змогу надати клієнтові належним способом інформацію про його проблему. Особливо це важливо в разі необхідності конкретизації делікатних анатомо-фізіологічних, особистісних або фінансових подробиць. Збереження медичної таємниці як однієї з фундаментальних основ медичної етики та деонтології є безумовним та беззаперечним правом пацієнта! Слід зазначити, що це право не лише формалізоване у підручниках, а й регламентоване чинним законодавстом України та міжнародними правовими актами [1; 2].

Наступним логічним принципом поводження зі скаржниками є демонстрація персональної уваги до клієнта. Зазначений підхід $є$ стандартною настановою в роботі всього персоналу приватних клінік, як при звичайному поточному обслуговуванні, так і в ситуаціях розбору скарг. Клієнтоорієнтованість в даному аспекті передбачає концентрацію спілкування одного, двох працівників закладу зі скаржником. Важливість персональної уваги актуалізується вразливістю клієнта, який вже незадоволений обслуговуванням, демонструє дискомфорт, негативні емоції. 
Тому, залишення такого клієнта без уваги може лише погіршити ситуацію. Є вкрай неетичним породжувати в свідомості незадоволеної особи більші страхи та тривоги. Обмеження комунікації можуть бути розцінені клієнтом як спроби щось приховати, або уникнути відповідальності. Натомість, компетентне, уважне та доброзичливе ставлення до скаржника стає запорукою успішного завершення діагностики та розбору скарги. $€$ дуже бажаними лаконічні, але зрозумілі роз'яснення для пацієнта, який очікує на результат, всіх етапів розбору. Це також є корисним, внаслідок складності медичної діяльності, про що не завжди поінформовані наші клієнти. На тлі інформаційного перевантаження та полегшеного доступу до медичної інформації деякі необізнані особи створюють для себе хибну уяву про стан власного здоров'я та методів його відновлення. Інші скарги можуть виникати як результат психоемоційної акцентуації особистості, старіння населення та інших причин. При систематичному аналізі скарг ми часто встановлюємо відсутність об'єктивних для них підстав. В різні звітні періоди частка таких скарг може сягати половини. Тим не менше, в умовах медичного закладу персонал використовуючи принципи етики та деонтології має утримувати невдоволеного клієнта в центрі уваги. Відповідальні лікарі профресійно спілкуються з усіма категоріями пацієнтів, обов'язково пам'ятаючи про те, що кожна хвороба має психологічний компонент [3]. Персонал клініки своєю привітністю та увагою налаштовує невдоволеного клієнта на врівноваженість та позитивний результат. Також, при налагодження комунікації, слід не забувати про мовні та лексичні особливості скаржника, це буде створювати для нього більш комфортні умови. Персоналізацію уваги необхідно актуалізувати крилатим висловом відомого лікаря Володимира Бехтєрєва: «Якщо хворому після розмови з лікарем не стало легше, то це не лікар!»

При розборі скарг досить часто клієнти одразу вимагають зустрічі з керівництвом клініки. Такі випадки найчастіше трапляються зі скаргами, котрі, або стосуються фрінансових відшкодувань, або генеруються особами, які $є$ досить наполегливими та непоступливими у власному бажанні досягти мети скарги. Перший, згаданий варіант, в приватній медичній практиці має особливо чутливе значення внаслідок негативного впливу повернення грошей із бюджету клініки. А це недоотриманий прибуток, що забезпечує виплати зарплатні, компенсації накладних витрат, поповнення фондів розвитку закладу та інше. В такий ситуації керівник клініки опиняється в ще більш складній ситуації, коли до процесу розбору скарги долучається максимальна кількість суб'єктів. Медична етика та деонтологія вимагає безпристрасного підходу для з'ясування істини та фрормування належного реагування і поводження зі скаргою. Перша особа компанії, що особисто приймає скаржника повинна забезпечити комфортні умови бесіди та ії конфіденційність. Необхідно із певною симпатією уважно слухати, слухати й слухати невдоволеного клієнта, нотувати основні тези, обережно уточнювати деталі й одночасно коректно керувати розмовою для ретельного з'ясування всіх деталей та встановлення об'єктивних фактів. Обов'язково демонструється фіксація скарги у відповідних облікових формах або електронних додатках. По завершенні викладу змісту скарги, директор має 3 повагою щиро висловити жаль, щодо ситуації, яка склалася і запевнити клієнта у тому, що скарга буде розглянута належним чином. Також, в деяких випадках, доцільним може бути запрошення відповідальної особи або профільного спеціаліста для надання коментарів, докладних роз'яснень, різноманітних дозвільних документів, стандартів, видання доручень, тощо. До сучасного стану розвитку партнерської моделі взаємовідносин між медичним персоналом та пацієнтами органічно вписується погоджувальний підхід щодо виконання та контролю заходів з розгляду скарги. Абсолютна переважна кількість невдоволених клієнтів схвально ставляться до власної участі в таких розборах. Це підвищує довіру до клініки та впевненість в справедливості результатів розбору, навіть якщо отримується результат не на користь скаржника. Але, відкритість та залучення самих пацієнтів, як власників персональних даних та інформації про стан власного здоров'я, сприяють максимальному дотриманню етикоюридичних норм в делікатних питаннях оцінки якості роботи персоналу приватної медичної клініки. Керівник клініки, під час бесіди для прогнозування перебігу розгляду скарги, може наводити узагальнену інформацію про аналогічні прецедентні випадки, які мали місці раніше та відповідні фріналізовані рішення керівництва і навіть фрормулювати попереднє рішення. Також, у повноваженнях директора $є$ можливості вирішення питань іншими альтернативними способами або в інших медичних установах. Це визначається безпосередніми особливостями невдоволеності пацієнта, пам'ятаючи про те, що головним у діяльності приватної клініки є повне 
задоволення медичних потреб клієнтів. Слід зазначити, що розбір скарг повинен бути одним 3 основних бізнес-процесів, що є невід'ємною частиною системи управління якістю в клініці та бути на постійному моніторингу у керівництва [4].

Важливим етичним аспектом завершення розгляду скарг $є$ чітке виконання наданих невдоволеному клієнту обіцянок щодо ефективності виконання процедури та надання повної всеохоплюючої відповіді на питання. Відповідність між попереднім словом керівника та фінальним звітом підвищує довіру до клініки і готовність ще раз повернутися до неї. Особливо це актуалізується в разі швидкого усунення виявлених недоліків, а згадана «скарга-подарунок» може стати приводом до приємної подяки від клініки. Ці подяки, або бонуси, слід застосовувати стримано та з усією обережністю. Не можна допускати абсолютної монетизації процесу розгляду скарг. В такому випадку клініка апріорі визнає свою провину та намагається неформально вирішити проблеми шляхом підкупу, а це ставить репутацію закладу під сумнів! Подяки можна розглядати у вигляді двох варіанті: як бонуси для вдячності клієнту, якій допоміг виявити та усунути невідповідність, або як пряму компенсацію невиправданих витрат та моральної шкоди. Вирішення подібних завдань покладається виключно на керівника приватного медичного закладу, якій повинен виконувати функцію лідера, що бере на себе найважчі проблеми і не перекладає їх на своїх підлеглих або ігнорує скаржників. Директор приватної клініки, застосовуючи принципи медичної етики та деонтології, повинен ставати психологом, що поважає клієнта-пацієнта-людину-громадянина-особистість, повинен оминати гострі кути для прийняття «соломонового» рішення, яке забезпечить оптимальний результат в сучасних мінливих умовах національної системи охорони здоров'я [5].

Для наочності наводимо два приклади розбору скарг, які мали місце в практиці нашої клініки:

1. Пацієнт С., звернувся до клініки з приводу необхідності проведення на дому ультразвукового діагностичного дослідження (УЗД) органів черевної порожнини. Пацієнт відносився до групи осіб з обмеженої мобільністю. Така послуга потребує відповідної реєстрації в медичній інформаційній системі, бронювання санітарного транспорту з УЗД-апаратом та організації виїзної бригади. Але, по настанні зазначеного ранкового часу послугу не було надано, а перенесення її на більш пізній час виключало інформативність діагностики, про що й поскаржився клієнт. При розборі скарги з'ясувалося, що: - медичний реєстратор припустився помилки під час офрормлення замовлення; - інформація про виїзд була занесена в іншу графу медичної інформаційної системи, що унеможливило вчасне прибуття до клієнта; - внаслідок малорухомості пацієнт не може самостійно прибувати до клініки для обстеження; - стан здоров'я скаржника вимагає діагностики та лікування. Клініка визнала недолік у своїй роботі і, враховуючи всі обставини, запропонувала клієнтові безкоштовне УЗД на дому на наступний ранок, що і було реалізовано. По завершенні процедури клініка отримала подяку від пацієнта за швидке та якісне виправлення негативної ситуації.

2. Пацієнтка П., звернулася до клініки для проведення лабораторного обстеження перед візитом до лікаря-спеціаліста. Попередньо, при реєстрації в медичній інформаційній системі, їй було надано вичерпну інформацію про порядок підготовки до здавання та забору біологічного матеріалу. В призначений день зранку, пацієнтка прибула в маніпуляційний кабінет клініки, де без будь-яких особливостей або зауважень було проведено забір зразків крові. Медичний персонал надав інформацію щодо отримання результатів та завершив всі подальші необхідні дії щодо преаналітичного етапу обстеження. Слід зауважити, що наша клініка має договір на обслуговування 3 лабораторної справи з відомим лабораторним центром, якій має всі національні дозвільні документи та міжнародні сертифікати відповідності. Однак, вже через два дні зазначена клієнтка звернулася до клініки із скаргою про недовіру до отриманих лабораторних результатів та вимогою у поверненні витрачених коштів. Як аргумент на свою користь вона навела результати аналогічних показників, але вже з іншої лабораторії. При розгляді скарги з'ясувалося, що: - час забору зразків був невідповідним до вимог, що впливає на їх величину; - пацієнтка не змогла підтвердити належну підготовку під час повторного забору зразків; - всі розбіжні показники за своєї природою є дуже варіабельними, а відхилення були не суттєвими; - альтернативна лабораторія відмовилася надавати підтверджуючі документи щодо стандартизації та відповідності виробничих процесів. Тобто, проведення лабораторних досліджень в двох різних лабораторіях не можна було порівнювати за об'єктивних причин. Пацієнтці було коректно відмовлено у компенсації витрат, але запропоновано роз'яснення від 
лікаря щодо інтерпретації первинних результатів. Після бесіди зі спеціалістом конфліктна ситуація була вичерпана.

Висновки. Таким чином, дотримання принципів медичної етики при розборі скарг в практиці приватних медичних закладів має принципову важливість та впливає на кінцеву якість надання медичних послуг. Керівництво клінік повинно забезпечити безперервне виконання всіх елементів бізнес-процесу діагностики, розгляду та вирішення питань зазначених у скаргах. Належне застосування етичних підходів до спілкування зі скаржниками сприяє розвитку медичного закладу та розширює можливості пацієнтів у вирішенні проблем з власним здоров'ям.

\section{Література}

1. Основи законодавства України про охорону здоров'я [Електронний ресурс] - Режим доступу: https://zakon.rada.gov.ua/laws/show/2801-12\#Text.

2. Міжнародний кодекс медичної етики [Електронний ресурс] - Режим доступу: https://zakon.rada.gov.ua/laws/show/990_002\#Text.

3. Пилипенко, Н. Г. Психологічні аспекти якості медичного обслуговування: сучасні проблеми та перспективи дослідження / Н. Г. Пилипенко // Клінічна та профілактична медицина. - 2019. - Т. 2. - № 8. - С. 90-96.

4. ДСТY ISO 9001:2015 (ISO 9001:2015, IDT) «Системи управління якістю. Вимоги». - К. : ДП «УкрНДНЦ», 2016. - 22 с. - (Національний стандарт України).

5. Підручник з лікарської етики. Переклад з англ. за ред. акад. АМН України, голови комітету з лікарської етики Всеукраїнського Лікарського Товариства (ВУЛТ) Любомира Пирога. - 2009. - 139 с.

\section{References}

1. Zakon Ukrainy "Osnovy zakonodavstva Ukrainy pro okhoronu zdorovia": vid 19 lystopada 1992 roku, № 2801-XII [Law of Ukraine "Fundamentals of the legislation of Ukraine on health care" from November 19, 1992 № 2801-XII]. zakon.rada.gov.ua. Retrieved from https://zakon.rada.gov.ua/laws/show/2801-12\#Text [in Ukrainian].

2. Mizhnarodnyi kodeks medychnoi etyky [International Code of Medical Ethics]. zakon.rada.gov.ua. Retrieved from https://zakon.rada.gov.ua/laws/show/990_002\#Text [in Ukrainian].

3. Pylypenko, N. H. (2019). Psykholohichni aspekty yakosti medychnoho obsluhovuvannia: suchasni problemy ta perspektyvy doslidzhennia [Psychological aspects of quality of medical care: modern problems and prospects of research]. Klinichna ta profilaktychna medytsyna - Clinical and preventive medicine, 8 (2), $90-96$ [in Ukrainian].

4. Systemy upravlinnia yakistiu. Vymohy [Quality management systems. Requirements]. (2016). DSTU ISO 9001:2015 (ISO 9001:2015, IDT). Kyiv: DP «UkrNDNTs» (Natsionalnyi standart Ukrainy) [in Ukrainian].

5. Pyroh, L. (Ed). (2009). Pidruchnyk z likarskoi etyky [Medical Ethics Manual]. BF «Tretie Tysiacholittia» [in Ukrainian].

Бібліографічний опис для цитування :

Надійшла 10.11.2019

Герасименко, П. В. Етичні аспекти розбору скарг у приватній медичній практиці / П. В. Герасименко, О. В. Герасименко // Проблеми соціальної роботи: філософрія, психологія, соціологія. - 2019 - № 2 (14) - С. 13-18. 